\title{
GGR (Geranylgeranyl Reductase) Expression Affects the Allelopathic Response to Arabidopsis Allelochemicals
}

\author{
Débora Almeida Alcântara da Silva ${ }^{1}$, Juliane Laner de Toledo ${ }^{1}$, Flaviani Gabriela Pierdoná ${ }^{1}$, \\ Gabriel Sergio Costa Alves ${ }^{2}$, Michelle de Souza Fayad André ${ }^{1}$, Natalia Faustino Pires ${ }^{1}$, \\ Thaís de Moura Cipriano ${ }^{3}$, Fernando Araripe Gonçalves Torres ${ }^{2}$, Conceição Eneida dos Santos Silveira ${ }^{1}$, \\ Francisco José Lima Aragão ${ }^{3} \&$ Luiz Alfredo Rodrigues Pereira ${ }^{1}$ \\ ${ }^{1}$ Department of Botany, University of Brasilia, Brazil \\ ${ }^{2}$ Cell Biology Department, University of Brasilia, Brazil \\ ${ }^{3}$ Brazilian Agricultural Research Corporation/National Centre of Genetic Resources, Brazil \\ Correspondence: Luiz Alfredo Rodrigues Pereira, Plant Biotechnology Laboratory, University of Brasilia, \\ Campus Darcy Ribeiro, Department of Botany, Postal Code 70910-900, Brasilia, Brazil. Tel: 55-61-3107-2961. \\ E-mail: larp@unb.br
}

Received: April 8, 2018

doi:10.5539/jas.v10n7p122
Accepted: May 9, 2018 Online Published: June 15, 2018

URL: https://doi.org/10.5539/jas.v10n7p122

The research is financed by the Coordination for the Improvement of Higher Level-or Education-Personnel (CAPES), the Brazilian Council of Research (CNPq), and the Support Research of the Federal District Foundation (FAP-DF).

\begin{abstract}
Allelopathy involves the release of compounds into the environment that affects the growth and development of other organisms. This phenomenon may lead to the production of compounds less harmful to the environment than traditional herbicides used in weed control. In plants, terpenes have been identified as components of allelochemicals and are synthesized by enzymes named as geranylgeranyl diphosphate synthases (GGPPS). There are about 12 GGPPS genes in Arabidopsis, among which is GGR. This work aims to study the association between the expression levels of $G G R$ and the allelopathic response of sesame seedlings to Arabidopsis leaf extracts. Hence, the GGR gene was inserted into Arabidopsis with the purpose to investigate the allelopathic effects of $G G R$ expression levels on sesame seedlings. GGR expression levels were quantified by RT-PCR in both transgenic and non-transgenic [wild-type (WT)] lines. It has been observed that both wild-type and GGR expressing transgenic lines inhibited the growth of sesame seedlings. However, it is noteworthy that the phytotoxicity of extracts from $G G R$ lines were greater than WT extracts. RT-PCR analysis of $G G R$ expression revealed that WT plants had higher levels of $G G R$ expression than $G G R$ transgenic lines, which suggests that a homologous-dependent gene silencing (HDGS) occurred in GGR lines. GGR is part of an enzyme complex that works as a hub that determines the types of terpenes produced in Arabidopsis chloroplasts. The present data indicates that decreases in $G G R$ expression may have favoured the production of terpenes with stronger allelopathic capacity in Arabidopsis leaves.
\end{abstract}

Keywords: Arabidopsis thaliana, geranylgeranyl diphosphate synthase (GGPPS), geranylgeranyl reductase (GGR), geranylgeranyl diphosphate (GGPP), allelopathy, terpenes

\section{Introduction}

Allelopathy is a phenomenon that comprises interactions among organisms that directly or indirectly affects many physiological/biochemical processes and biological systems (Pereira et al., 2017). Moreover, this phenomenon is mediated by secondary metabolites (Formagio et al., 2010).

All living organisms produce primary and secondary metabolites. Secondary metabolites are organic compounds, many of which synthesized by plants and can be restricted to determined species or groups of plants. While compounds derived from the primary metabolism are essential for plant survival, secondary metabolites are not crucial (Demain \& Fang, 2000). However, these substances may confer to organisms that produce them certain adaptive advantages that favour their survival by enhancing their competitiveness (Demain \& Fang, 2000). 
Among the secondary metabolites, the terpene (or terpenoid) class is the largest and most diverse. Terpenoids are abundantly produced by plants, and there have been isolated more than 55,000 of these compounds (Maimone \& Baran, 2007). These metabolites are involved in protection against pathogens, plant competition, plant hormones, pollination and herbivore prevention (Tholl \& Lee, 2011). In addition, they are precursors of important biomolecules such as carotenoids, plant hormones (abscisic acid/gibberellins), tocopherols, phytol chain of chlorophyll, and plastoquinones (Chao et al., 2014).

The synthesis of terpenoids (isoprenoids) units has two independent routes: the mevalonic acid (MVA) route; and, the 2-C-methyl-D-erythritol 4-phosphate route (DOXP/MEP) pathway (Wanke, Skorupinska-Tudek, \& Swiezewska, 2001; Carretero-Paulet et al., 2002). The MVA pathway produces isopentenyl pyrophosphate (IPP)/dimethylallyl diphosphate (DMAPP) in the cytosol, and DOXP/MEP pathway, which takes place in plastids and results in the formation of these two isomers (Wanke et al., 2001; Rodríguez-Concepción \& Boronat, 2002). All terpenoids are originated from the condensation of IPP and DMAPP (Beck et al., 2013). Therefore, the sequential head-to-tail addition of IPP units to DMAPP yields diphosphates geranyl diphosphate (GPP-10 Carbons), farnesyl diphosphate (FPP-15 Carbons), and geranylgeranyl diphosphate (GGPP-20 Carbons) (Valduga et al., 2009). Moreover, GPP, FPP, and GGPP are substrates for the synthesis of monoterpenoids (two isoprene units), sesquiterpenoids (three isoprene units), diterpenoids (four isoprene units) (Auburg, Lecharny, \& Bohlmann, 2002; Harrison et al., 2006). Geranylgeranyl diphosphate synthase (GGPPS) catalyses the addition of IPP to DMAPP, GPP, and FPP to form the different types of terpenoids (Vandermoten, Haubruge, \& Cusson, 2009).

In Arabidopsis, 12 genes of the GGPP synthase family were identified (Okada, Nakagawa, Kawamukai, \& Kamiya, 2000; Beck et al., 2013). Although there are differences concerning the gene nomenclature among the authors, in this work we have adopted the nomenclature proposed by Okada et al. (2000). GGPP synthases are found in different subcellular compartments, as well as in different cell types, tissues and organs (Scolnik \& Bartley, 1994; Okada et al., 2000; Beck et al., 2013). Hence, GGPP synthases were observed in hypocotyl epidermal cells and stomatal guard cells in A. thaliana, which indicates that each GGPP synthase gene has a tissue-specific expression pattern (Okada et al., 2000).

Besides being a good model for molecular studies, it turns out that Arabidopsis can also be a suitable plant to study allelopathic interactions. Arabidopsis produces a vast variety of secondary metabolites such as anthocyanins, flavonoids, esters, glycosinolates, camalexins, and terpenoids (Kliebenstein, 2004). It has been shown that plant allelochemicals may contain alkaloids, phenols, steroids, long chain fatty acids, unsaturated lactones, and, of course, terpenes (Formagio et al., 2010). For instance, momilactone B, a diterpene, was found to inhibits accumulation of several enzymes in Arabidopsis such as subtilisin-like serine protease, malate synthase, and the breakdown of cruciferin 2 (Kato-Noguchi \& Kitajima, 2015)

There is an increased concern with the careless use of herbicides due to their harmful effects on the environment. Hence, allelopathy can be an alternative to achieve a more ecologically oriented agriculture as allelochemicals may be used as bioherbicides (Soltys, Krasuska, Bogatek, \& Gniazdowska, 2013; F. Cheng \& Z. Cheng, 2015). Furthermore, the use of allelochemicals extracts from several plant species has been investigated for weed control. For instance, extracts from Eugenia dysenterica (Pina, Borghetti, Silveira, \& Pereira, 2009), Sonchus oleraceus (Gomaa et al., 2014), and Sorghum bicolor (Amali, Jayasurya, \& Ignacimuthu, 2014) have been shown to inhibit the germination and growth of plants. Moreover, molecular studies of genes associated with allelochemical compounds will help to understand the molecular mechanisms involved in allelopathic responses, which can support bioengineering programs to enhance the effectiveness of allelochemicals.

Therefore, to determine if terpenes have a relevant role in allelopathic response, Arabidopsis thaliana plants (Columbia ecotype) were transformed to overexpress the $G G R$ gene (coding for a geranylgeranyl reductase) under control of CaMV 35S promoter. GGR (At4g38640) encodes an enzyme associated with the synthesis of monoterpenes, which is usually found in plastids and constitutively expressed in leaves, stems, roots, and flowers of $A$. thaliana (Keller, Bouvier, D’Harlingue, \& Camara, 1998; Wang \& Dixon, 2009; Beck et al., 2013; Chen, Fan, \& Wang, 2015). Besides, after the confirmation of the presence of $G G R$ transgene in Arabidopsis transformed plants, the allelopathic effects of leaf extracts from wild-type (WT) and transgenic lines on sesame seedlings were investigated. Finally, a real-time PCR GGR expression analysis in Arabidopsis WT and GGR lines was carried out to quantify and compare the expression levels of the native and transgene in these plants. Hence, a correlation between GGR expression levels and the allelopathic response to Arabidopsis extracts could be established. 


\section{Material and Methods}

\subsection{Arabidopsis Growth}

Arabidopsis thaliana L. (Columbia ecotype) seeds were donated by the Apomixis Laboratory of Embrapa Genetic Resources and Biotechnology (CENARGEN). Approximately 15 seeds were placed in each pot with Germinar Leve ${ }^{\circledR}$ substrate. The pots were placed in a BOD growth chamber with $16 \mathrm{~h}$ photoperiod, at $20{ }^{\circ} \mathrm{C}$, in the Laboratory of Molecular Biology of Plants, Department of Botany, University of Brasilia.

The seeds germinated between 6-7 days. After the differentiation of first inflorescence (4-5 weeks after germination), the stems were cut to encourage the emergence of new inflorescences. The seeds were harvested and stored at $4{ }^{\circ} \mathrm{C}$.

\subsection{Vector Construction for Expressing the GGR Gene and Plant Transformation}

The GGR gene, coding for the geranylgeranyl diphosphate synthase (GGR-At4g38640), described by Okada et al. (2000) was cloned into the vector pYL436 (Rubio et al., 2005) under control of the 35S CaMV promoter, generating the pYL436-GGR vector. Agrobacterium tumefaciens transformation with the pYL436-GGR vector was accomplished by electroporation.

Then, the transformed cells were incubated under shaking at $180 \mathrm{rpm}$ for $1 \mathrm{~h}$. Subsequently, streak plates were prepared with transformed Agrobacterium cells in LB3 medium (agar $1 \mathrm{~g} \mathrm{~L}^{-1}$ ) containing the antibiotics spectinomycin $50 \mu \mathrm{g} \mathrm{mL}^{-1}$ and rifampicin $50 \mu \mathrm{g} \mathrm{mL}^{-1}$. After $48 \mathrm{~h}$, isolated bacterial colonies were seen, which indicated the presence of Agrobacterium resistant to both antibiotics. Culture stock solutions ( $20 \%$ glycerol, v/v) GGR transformed Agrobacterium were prepared in liquid LB3 medium with spectinomycin and rifampicin antibiotics. Cultures were stored at $-80^{\circ} \mathrm{C}$ for further transformation of Arabidopsis thaliana.

\subsection{Transformation of Arabidopsis thaliana and Selection of Transgenic Plants}

Arabidopsis plants (10 to 15 individuals) were grown in $10 \times 10 \mathrm{~cm}$ pots, at $20^{\circ} \mathrm{C}$, and $16 \mathrm{~h}$ photoperiod. After, the plants had reached the reproductive age (approximately $21 \mathrm{~d}$ ), the first inflorescence was removed to stimulate the differentiation of new inflorescences with a higher number of flowers.

Therefore, Agrobacterium-harboring pYL436-GGR vector were used to transform A. thaliana. For the transformation, a preculture was made by inoculating $5 \mathrm{~mL}$ of liquid culture (LB3 medium plus spectinomycin and rifampicin antibiotics) of GGR transformed Agrobacterium into a falcon tube. This pre-inoculum was incubated under shaking $(180 \mathrm{rpm})$, at $28^{\circ} \mathrm{C}$ for $48 \mathrm{~h}$. Subsequently, $1 \mathrm{~mL}$ of the pre-inoculum was added to 250 $\mathrm{mL}$ of LB3 containing spectinomycin and rifampicin antibiotics. Then, this solution was incubated under stirring $(180 \mathrm{rpm}), 28^{\circ} \mathrm{C}$, for $24 \mathrm{~h}$. The GGR Agrobacterium transformed cultures were then centrifuged at $600 \mathrm{rpm}$ for $10 \mathrm{~min}$ at room temperature. The pellet was resuspended in $250 \mathrm{~mL}$ of $5 \%$ sucrose solution, to which was added $0.05 \%$ Silwet-L77 surfactant (Momentive).

Thus, Arabidopsis thaliana inflorescences were dipped in this Agrobacterium solution for 2 to $3 \mathrm{~s}$ under gently rocking. After dipping, the plants were covered with plastic film $(24 \mathrm{~h})$ to maintain the humidity and increase the absorption of the solution. The next day, the plants were returned to the initial growth conditions with regular watering. The whole transformation proceedings were repeated one week later to increase the efficiency of the technique. Two weeks later, seeds from the Agrobacterium exposed plants were collected stored at $4{ }^{\circ} \mathrm{C}$.

Then, the collected seeds were disinfested in a solution composed of $70 \%$ ethanol and $0.05 \%$ Triton X-100, and, subsequently rinsed in $95 \%$ ethanol and placed again in the wash solution. Next, approximately 25 seeds were put out on plates with the MS medium (Murashige \& Skoog, 1962) containing gentamicin antibiotic (10 $\mu \mathrm{g}$ $\left.\mathrm{mL}^{-1}\right)$. The plates were placed in a germination chamber BOD, $16 \mathrm{~h}$ photoperiod, at $20^{\circ} \mathrm{C}$. Three weeks later, gentamicin resistant Arabidopsis seedlings were transferred to pots with substrate and grown at $20{ }^{\circ} \mathrm{C}, 16 \mathrm{~h}$ photoperiod, and regular watering to obtain transformed seeds. The transformed seeds were collected and germinated in MS medium with gentamicin $\left(10 \mu \mathrm{g} \mathrm{mL}^{-1}\right)$ to produce the first-generation of transformed plants that were analysed by PCR for validation of transgenic. The PCR validated Arabidopsis transgenic plants were grown again as previously described to obtain the F2 generation. Five GGR Arabidopsis transgenic lines were obtained and termed as $4 \mathrm{GA}, 4 \mathrm{~GB}, 4 \mathrm{GC}, 4 \mathrm{GD}$, and $4 \mathrm{GM}$. Due to the availability of seeds, the bioassays and real time PCR experiments were performed only with 4GA, 4GB, 4GC, and 4GM.

\subsection{Transgenic Plants Confirmation}

For PCR validation of GGR transgenic Arabidopsis plants, specific primers were designed for a combined sequence of T-DNA (pYL436) and GGR gene. Primer sequences were: pYL436 Forward (5'GCCGGTCTAGGTATTTTTACAAC-3') and GGR Reverse (5'-AGGATCGTCGTCCATACAGG-3'). The PCR 
conditions were: $95^{\circ} \mathrm{C}$ for $5 \mathrm{~min}$, plus 35 cycles at $95^{\circ} \mathrm{C}$ for $30 \mathrm{~s} ; 60^{\circ} \mathrm{C}$ for $1 \mathrm{~min} ; 72{ }^{\circ} \mathrm{C}$ for $1 \mathrm{~min}$, and a 7 -min period for final extension at $72{ }^{\circ} \mathrm{C}$.

\subsection{Allelopathic Bioassay}

Two experiments were done to measure the biological activity of WT and GGR transgenic Arabidopsis leaf extracts. The first experiment used aqueous extracts, and in the second, the extraction of allelochemicals was made with organic solvents. Therefore, the allelopathic bioassays used leaves from WT and GGR transgenic Arabidopsis plants germinated and grown at $20^{\circ} \mathrm{C}$ and $16 \mathrm{~h}$ photoperiod. The target plant was sesame (Sesamum indicum L.) in both experiments.

\subsubsection{Bioassay With Aqueous Leaf Extract}

After 22 days of cultivation, leaves of WT A. thaliana and GGR transgenic plants were collected and dried up in an oven at $40{ }^{\circ} \mathrm{C}$ for a period of $24 \mathrm{~h}$. Subsequently, the $30 \mathrm{~g}$ of leaves from both plants were ground and mixed with $1000 \mathrm{~mL}$ of distilled water left at $4{ }^{\circ} \mathrm{C}$ for $24 \mathrm{~h}$, resulting in a $3 \%(\mathrm{w} / \mathrm{v})$ or $0.1 \%(\mathrm{w} / \mathrm{w})$ aqueous leaf extract. Then, the solution was vacuum filtered and further diluted to $1.5 \%$ and $0.75 \%(\mathrm{w} / \mathrm{v})$ or, $0.033 \%$ and $0.025 \%$ $(\mathrm{w} / \mathrm{w})$, respectively. The bioassays used four GGR transgenic lines: 4GA, 4GB, 4GC, and 4GM.

For each dilution, 10 sesame seeds of each plant line were put to germinate and grow in Petri dishes $(35 \times 10$ $\mathrm{mm}$ ) containing filter paper treated with $1 \mathrm{ml}$ of aqueous extract. Each plant line had three replicates for each treatment $[0.75 \%, 1.5 \%$, and $3.0 \%(\mathrm{w} / \mathrm{v})]$ or $[0.1 \%, 0.033 \%$, and $0.025 \%(\mathrm{w} / \mathrm{w})]$. The control had the same number of sesame seedlings grown in distilled water. The plants were placed to germinate and grow BOD chamber for a period of $7 \mathrm{~d}$. After the seven days, the shoot and root parts of the seedlings from all plants were measured using a digital calliper.

\subsubsection{Bioassay With Leaf Extracts From Organic Solvent}

All leaves from 40-day-old GGR transgenic (4GB) and WT Arabidopsis plants were collected, stored at $-80{ }^{\circ} \mathrm{C}$, and subsequently lyophilized for $48 \mathrm{~h}$. For the bioassays, $100 \mathrm{mg}$ of leaves of each plant line were used for the extraction of allelochemicals with the organic solvents. Each experiment had three treatments (extracts concentrations) and four replicates. The negative control consisted of sesame seeds grown with a commercial herbicide (glyphosate), and the positive control was composed of sesame seeds grown with water and organic solvent. The terpenes were extracted with a solution composed of two high polar organic solvents, hexane (70\%) and ethyl acetate (30\%), as described by Johnson, Hull-Sanders, and Meyer (2007). WT and 4GB GGR line Arabidopsis leaf extracts, as well as the negative control had the following concentrations: $500 \mathrm{ppm}, 1000 \mathrm{ppm}$ and $2000 \mathrm{ppm}$, or $1 \%, 2 \%$, and $4 \%(\mathrm{w} / \mathrm{w})$, respectively.

Therefore, sesame seeds were germinated and grown in Petri dishes $(35 \times 10 \mathrm{~mm})$ on germitest paper treated with $2 \mathrm{~mL}$ of Arabidopsis leaf extracts (500 ppm, $1000 \mathrm{ppm}$, and $2000 \mathrm{ppm})$ or [1\%, 2\%, and 4\% (w/w)]. However, before putting sesame seeds to germinate on the germitest paper, the Petri dishes were placed in a greenhouse at $50{ }^{\circ} \mathrm{C}$ for $4 \mathrm{~h}$ to evaporate all organic solvent present in the paper. Additionally, to keep control consistency, the same amount of organic solvents present in the samples was added to the positive control plate and left to evaporate as described. Subsequently, 10 sesame seeds were plated and regularly watered with sterile distilled water ( $1 \mathrm{~mL}$ of water each time). The growth and development of the sesame seeds took place in a growth chamber at $25^{\circ} \mathrm{C}, 16 \mathrm{~h}$ photoperiod for $7 \mathrm{~d}$.

Sesame seedlings development were evaluated by measuring the shoot and root lengths using a digital caliper, at the $7^{\text {th }}$ day of cultivation. The growth data were analysed by ANOVA, and the differences among the means were tested by the Tukey test $(\mathrm{p}<0.05)$, using Bioestat 5.0 software.

\subsection{GGR-Transgene Expression Analysis by Real-Time PCR}

Arabidopsis GGR transgenic lines (4GA, 4GG, 4GC, and 4GM) and WT seeds were grown as described previously. Total RNA was extracted from leaves of GGR transgenic and WT 5-week-old plants using TRIzol ${ }^{\mathrm{TM}}$ (Invitrogen) method according to manufacturer's instructions. The integrity of RNA from each sample was checked by running a denaturing checking RNA gel. The RNA samples were treated with DNase-RNase free to eliminate all traces of genomic DNA and then quantified on NanoPhotometer ${ }^{\mathrm{TM}}$ (Implen ${ }^{\mathrm{TM}}$ ) nano-spectrophotometer. Subsequently, the RNA samples were used to synthesize the cDNA using the Improm-II Reverse Transcriptase ${ }^{\mathrm{TM}}$ kit (Promega $^{\mathrm{TM}}$ ). cDNAs were synthesized using the Improm-II Reverse Transcriptase ${ }^{\mathrm{TM}}$ kit (Promega ${ }^{\mathrm{TM}}$ ) according to the manufacturer's instructions. Therefore, $1 \mu \mathrm{g}$ of DNase-treated RNA, $0.5 \mu \mathrm{g}$ primer oligo dT and nuclease-free. The tubes samples were incubated in a thermocycler at $70{ }^{\circ} \mathrm{C}$ for $5 \mathrm{~min}$, and then at $4{ }^{\circ} \mathrm{C}$ for $5 \mathrm{~min}$ with Improm-II buffer, $25 \mathrm{mM} \mathrm{MgCl}_{2}, \mathrm{RNasin}^{\mathrm{TM}}$ ribonuclease inhibitor $\left(\right.$ Promega ${ }^{\mathrm{TM}}$ ) and Improm-II ${ }^{\mathrm{TM}}$ reverse transcriptase enzyme. Subsequently, RNA from each sample was added to 
the mix to a final concentration of $20 \mu \mathrm{L}$. The reverse transcriptase reaction condition was: $25{ }^{\circ} \mathrm{C}$ for 5 min (annealing), $42{ }^{\circ} \mathrm{C}$ for $60 \mathrm{~min}$ (extension) and $70{ }^{\circ} \mathrm{C}$ for $15 \mathrm{~min}$ (enzyme inactivation). Then, the cDNA samples were stored at $-20^{\circ} \mathrm{C}$.

After cDNA synthesis the samples were retreated with DNase to assure the absence of genomic DNA contamination (gDNA). Additionally, PCR analyses were carried out with primers for the actin2 (primer actin2 forward and reverse) and elongation factor (primer EF1 $\alpha$ forward and reverse) to verify that there was no trace of gDNA. The mentioned pair of primers were designed to anneal to different exons (actin2 and EFl $\alpha$ ), with at least one intron between the regions to be hybridized, in case of gDNA contamination (Table 1). The PCR reactions had the following conditions: for the initial DNA denaturation at $94{ }^{\circ} \mathrm{C}$ for 4 min, plus 35 cycles at $94^{\circ}$ $\mathrm{C}$ for $45 \mathrm{~s}$ (denaturation); $50^{\circ} \mathrm{C}$ for $1 \mathrm{~min}$ (annealing); $72{ }^{\circ} \mathrm{C}$ for $1 \mathrm{~min}$ (extension); and a final extension period of $5 \min$ at $72{ }^{\circ} \mathrm{C}$.

Table 1. Primer sequences used to check the absence of genomic DNA in cDNA samples for real-time PCR

\begin{tabular}{lllll}
\hline Primers & & Primer sequence $\left(5^{\prime}-3^{\prime}\right)$ & $\begin{array}{l}\text { Amplicon size } \\
\text { with no introns }\end{array}$ & $\begin{array}{l}\text { Amplicon size } \\
\text { with introns }\end{array}$ \\
\hline actin2 & $\begin{array}{l}\text { forward } \\
\text { reverse }\end{array}$ & $\begin{array}{l}\text { TAACTCTCCCGCTATGTATGTCGC } \\
\text { GAGAGAAACCCTCGTAGATTGGC }\end{array}$ & $131 \mathrm{pb}$ & $209 \mathrm{pb}$ \\
\hdashline EF1 $\alpha$ & $\begin{array}{l}\text { forward } \\
\text { reverse }\end{array}$ & GCACTGTCATTGATGCTCC & $404 \mathrm{pb}$ & $497 \mathrm{pb}$ \\
& GTCAAGAGCCTCAAGGAGAG & & \\
\hline
\end{tabular}

Quantitative real-time PCR (RTq-PCR) was used to quantify the relative expression of the $G G R$ gene (At4g38640) in WT plants and GGR transgenic lines (4GA, 4GB, 4GC, and 4GM). WT and transgenic lines had three biological replicates, and three technical replicates in the RTq-PCR analyses. The TaqMan ${ }^{\circledR}$ probes were purchased for the assay with the $G G R$ gene and for the endogenous controls that consisted of the constitutive genes actin 8 (ACT8-At1G49240) and RAD23C ubiquitin receptor (RAD23C-At3G02540). The TaqMan ${ }^{\circledR}$ assays had the following components: a pair of specific primers; a probe labelled with VIC fluorophore (in the case of $G G R$ ) or FAM ${ }^{\circledR}$ (for RAD23C and $\mathrm{ACT} 8$ ) at the $5^{\prime}$ ' end and an MGB (minor groove binder) quencher molecule at the 3 ' end.

The manufacturer's instructions of TaqMan ${ }^{\circledR}$ Universal Master Mix II with UNG (Applied Biosystems ${ }^{\mathrm{TM}}$ ) were used to prepare the reactions of each target in triplicates. These were prepared to a final volume of $10 \mu \mathrm{L}$, composed of $5 \mu \mathrm{L}$ of TaqMan ${ }^{\circledR}$ Universal Master Mix II; $4.5 \mu \mathrm{L}$ of composite cDNA and sterile milliQ water (1: 5), and $0.5 \mu \mathrm{L}$ of the assay corresponding Taqman ${ }^{\circledR}$ probe. All reactions were placed on 96 -well MicroAmp ${ }^{\circledR}$ (Applied Biosystems ${ }^{\mathrm{TM}}$ ) reaction plates and then amplified in a StepOne ${ }^{\circledR}$ thermal cycler (Applied Biosystems ${ }^{\mathrm{TM}}$ ) with the following conditions: $50^{\circ} \mathrm{C}$ for $2 \mathrm{~min}$, for incubation of uracil-N-glycosylase (UNG); $95^{\circ} \mathrm{C}$ for $10 \mathrm{~min}$, for polymerase activation; and, then 40 cycles of $95{ }^{\circ} \mathrm{C}$ for $15 \mathrm{~s}$ (denaturation), and $60{ }^{\circ} \mathrm{C}$ for 1 min (annealing/extension). Expression analyses were performed using StepOne ${ }^{\mathrm{TM}}$ software version 2.3. The relative amount of the genes of interest was obtained by using the $\mathrm{C}_{\mathrm{T}}$ comparison method $\left(\Delta \Delta \mathrm{C}_{\mathrm{T}}\right)$ (Wong \& Medrano, 2005). StepOne ${ }^{\mathrm{TM}}$ software has determined the relative abundance of the gene by comparing the amount of the target gene in each sample $(G G R)$ and the amount of the reference genes (ACT8 and RAD23C) in the samples. Results were expressed as relative GGR expression and compared through a variance analysis (ANOVA), and the means were compared by Student's t-test $(\mathrm{p}<0.05)$.

\section{Results}

\subsection{Selection of GGR Transformed Arabidopsis Plants and PCR Confirmation}

Putative transformed Arabidopsis were selected by placing plantlets in 10 plates containing MS medium with the antibiotic gentamicin $\left(10 \mu \mathrm{g} \mathrm{mL}{ }^{-1}\right)$. Consequently, the transformed seedlings could grow and develop in the presence of gentamicin, whereas those that were not resistant to the antibiotic were not pigmented and died (Figure $1 \mathrm{~A}$ ).

PCR analyses revealed that five out seven gentamicin selected plants had the transgene $G G R$, which were named: 4GA, 4GB, 4GC, 4GD, and 4GM (Figure $1 \mathrm{~B}$ ). The PCR showed that the real transformed plants had a DNA fragment of $250 \mathrm{bp}$, which corresponded to the fragment size expected amplified with the mentioned primers (Figure $1 \mathrm{~B}$ ). The transgenic line 4GD was not used in bioassays and real time PCR experiments because there were not enough seeds of this line for all experiments. 


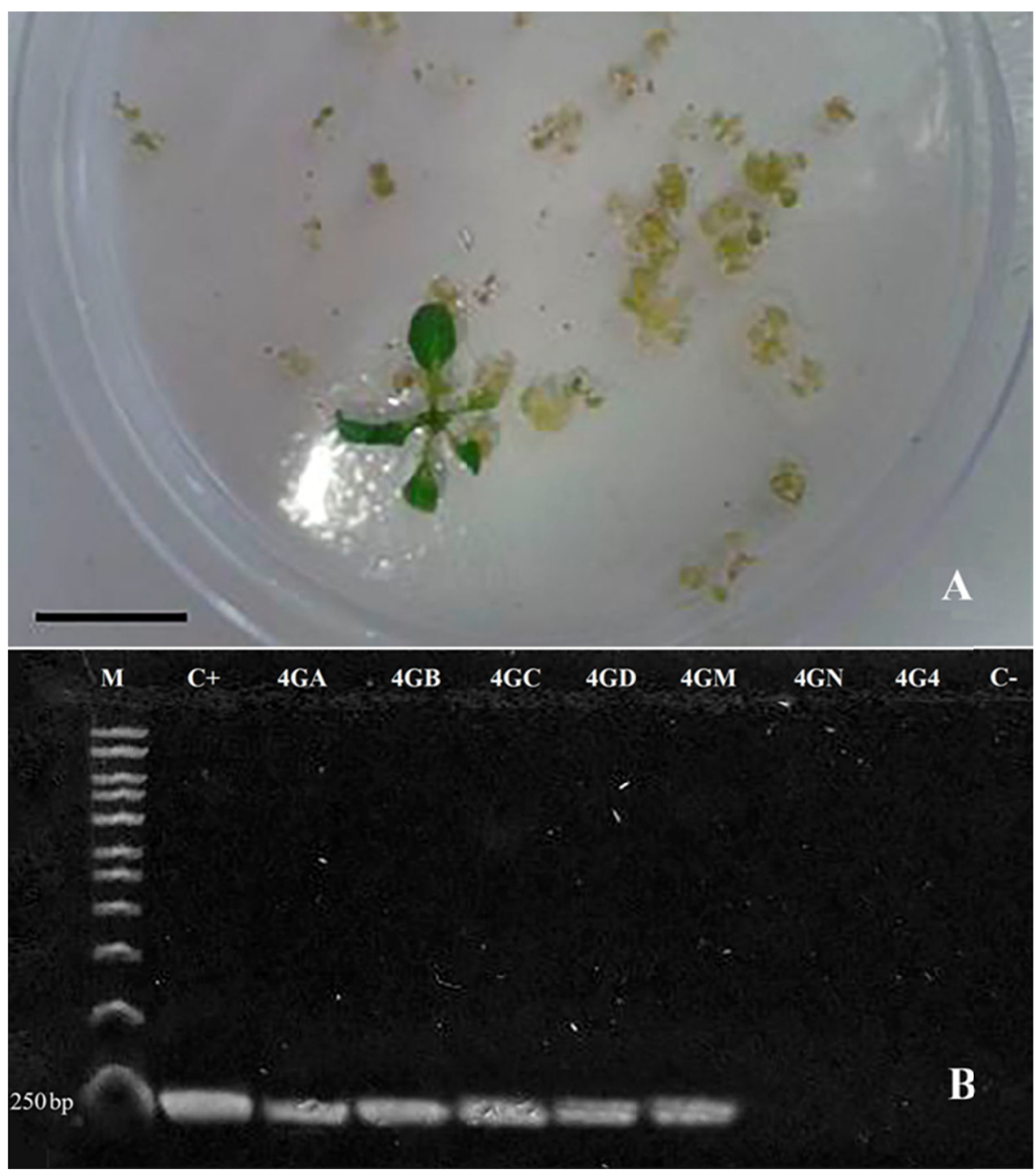

Figure 1. Transgenic plant selection. A) Plate containing MS medium with gentamicin $\left(10 \mu \mathrm{g} \mathrm{mL}^{-1}\right)$ showing a GGR transformed Arabidopsis seedling. Note that the seedling containing the GGR transgene is resistant to gentamicin and has green leaf primordia. Differently, those that did not have the transgene did not develop and were yellowish due to the presence of gentamicin in the medium. B) PCR analysis to detect the presence of the transgene (primers PYL436-forward; GGR-reverse). Samples from selected GGR transgenic lines 4GA, 4GB, $4 \mathrm{GC}, 4 \mathrm{GD}$, and $4 \mathrm{GM}$ had the amplicons of size of $250 \mathrm{pb}$, indicating the presence of the transgene. The 4GN and 4G4 plants that did not amplify the DNA fragment. The positive control showed the amplification of the 250 $\mathrm{bp}$ of the plasmid. The negative control composed of wild-type Arabidopsis genomic DNA did not amplified the fragment. $\mathrm{C}+=$ positive control (plasmid DNA); $\mathrm{C}-=$ negative controls (wild-type genomic DNA). $\mathrm{M}=$ Ladder $1 \mathrm{~Kb} 250 \mathrm{pb}$. Scale bar $=1 \mathrm{~cm}$

\subsection{Effects of the Leaf Extracts on the Growth of Sesame (Sesamum indicum L.) Seedlings}

\subsubsection{Aqueous Leaf Extracts}

To evaluate the allelopathic potential of WT and GGR transgenic plants, bioassays using different concentrations of leaf aqueous extracts from WT and the GGR lines (4GA, 4GB, 4GC and 4GM) were carried out. Initially, to determine if WT leaf extracts $(0.75 \%, 1.5 \%$, and $3.0 \%)$ had any phytotoxic effect on sesame seedlings were compared with water treatment (control). Subsequently, the effects of aqueous extracts from WT and transformed Arabidopsis lines were compared among each other, and the percentage of inhibition was calculated based on the control treatment. 


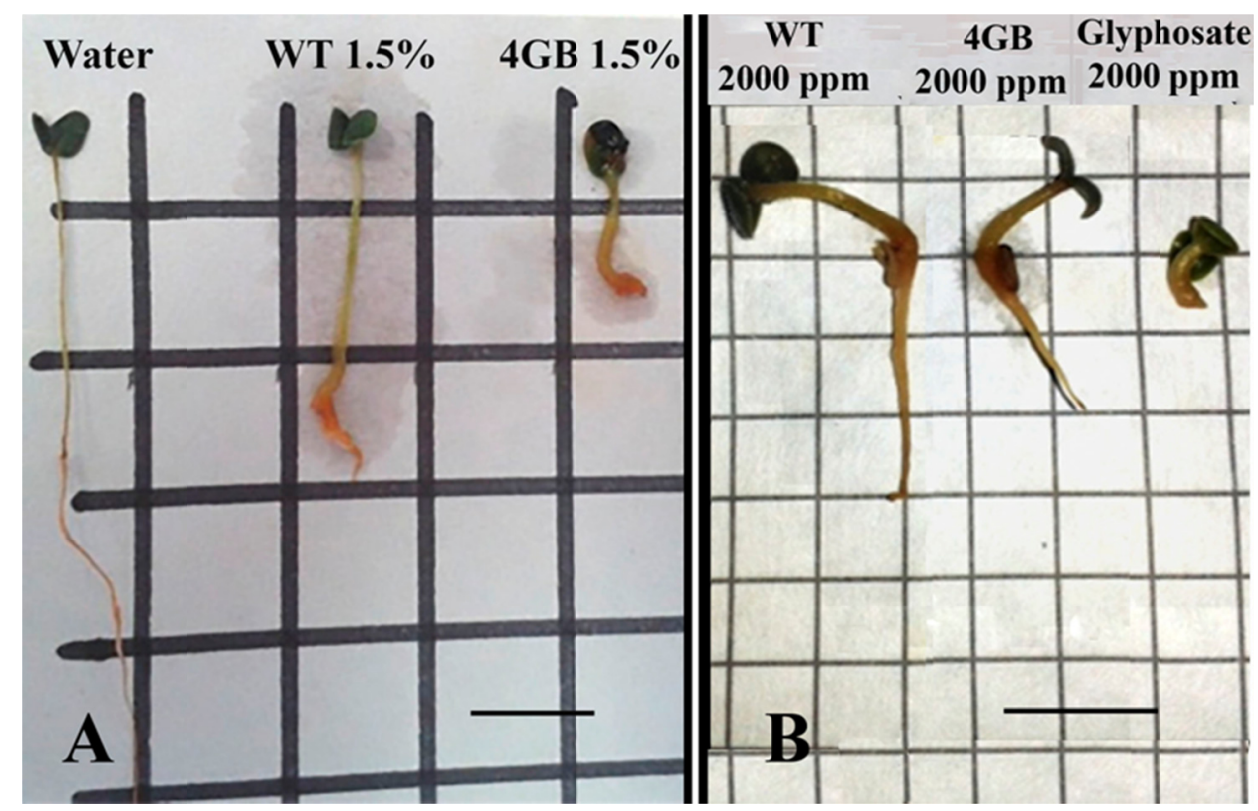

Figure 2. Sesamum indicum seedlings grown in water, aqueous leaf extract, organic solvent leaf extracts from WT and 4GB line Arabidopsis plants, and glyphosate. A) Sesame seedlings grown with water, WT and 4GB $1.5 \%$ aqueous leaf extracts. B) Sesame seedlings treated with organic solvent leaf extracts from WT, 4GB transgenic line, and glyphosate (2000 ppm). In both cases, the aqueous and organic solvent extracts from Arabidopsis plants inhibited the growth of sesame seedlings in comparison with those treated with water.

Scale bars $=0.5 \mathrm{~cm}$

Morphologically, sesame seedlings grown in contact with leaf extracts from WT and all transgenic lines (aqueous and organic solvent extractions) had signs of oxidation in the roots, which made them darker than those from control plants (Figures 2A and 2B). Furthermore, compared with seedlings grown in water, those seedlings exposed to Arabidopsis extracts had thicker roots, hypertrophied hypocotyl, and tended to bend upwards. Also, the higher the concentration of Arabidopsis extracts the shorter were the roots (Figure 2A).

Extracts from WT Arabidopsis leaves significantly inhibited both shoot and root growth of sesame seedlings. Thus, WT Arabidopsis leaf extracts diluted to 3\% induced a significant shoot elongation inhibition that ranged from about $26 \%$ to $40 \%$ in sesame seedlings (Table 2). Moreover, the inhibition effect of WT leaf extracts on roots were even greater. As shown in Table 2, WT leaf extracts inhibited sesame root growth up to almost $80 \%$ ( $3 \%$ extracts). Besides, even the lowest extract concentration $(0.75 \%)$ significantly reduced root growth by approximately $60 \%$ compared with the control treatment (Table 2 ). Furthermore, roots were consistently more inhibited by the extracts than shoots in all bioassays (Tables 2 and 3).

Table 2. Effect of the WT Arabidopsis thaliana leaf extract on root and shoot growth of Sesamum indicum seedlings

\begin{tabular}{|c|c|c|c|c|c|}
\hline Treatment & & Water & Extract $0.75 \%$ & Extract $1.5 \%$ & Extract 3\% \\
\hline \multirow[t]{2}{*}{ Length $(\mathrm{cm}) \pm \mathrm{SE}$} & Shoot & $1.808 \pm 0.116 \mathrm{a}$ & $1.105 \pm 0.061 \mathrm{~b}$ & $1.328 \pm 0.104 \mathrm{~b}$ & $1.092 \pm 0.092 \mathrm{~b}$ \\
\hline & Root & $2.293 \pm 0.246 \mathrm{~A}$ & $0.983 \pm 0.050 \mathrm{~B}$ & $0.667 \pm 0.016 \mathrm{~B}$ & $0.505 \pm 0.030 \mathrm{C}$ \\
\hline \multirow[t]{2}{*}{$\%$ of Inibition } & Shoot & $=$ & 38.88 & 25.99 & 39.60 \\
\hline & Root & - & 57.13 & 70.19 & 77.98 \\
\hline
\end{tabular}

Note. Means accompanied by the same letters within the same line do not statistically differ by the Tukey test (p $<0.05)$. SE: standard error.

Subsequently, bioassays were performed to investigate the effect of leaf extracts from $G G R$ transgenic Arabidopsis plants (4GA, 4GB, 4GC, and 4GM) on sesame seedlings. Usually, the inhibition effects on sesame shoot and roots of extracts from the transformed plants were greater than WT extracts (Table 3). 
Concerning sesame shoots, almost all leaf extracts from GGR Arabidopsis plants were significantly more inhibitory than WT extracts. Although, an extract concentration effect could not be noticed on sesame shoot growth, extracts from transgenic plants, in most cases, were two-fold more effective in restraining sesame shoot growth than WT extracts (Table 3).

Table 3. Effect of Arabidopsis thaliana leaf extract on root and shoot growth of Sesamum indicum L. seedlings grown with aqueous leaf extracts (1.5 and 0.75\%) from wild-type and GGR transgenic Arabidopsis plants and respective percentage of inhibition compared with seedlings grown in water

\begin{tabular}{|c|c|c|c|c|c|c|c|c|c|c|}
\hline \multirow{2}{*}{ Plant line } & \multicolumn{2}{|c|}{ WT leaf extract } & \multicolumn{2}{|c|}{ 4GA leaf extract } & \multicolumn{2}{|c|}{ 4GB leaf extract } & \multicolumn{2}{|c|}{ 4GC leaf extract } & \multicolumn{2}{|c|}{ 4GM leaf extract } \\
\hline & $0.75 \%$ & $1.5 \%$ & $0.75 \%$ & $1.5 \%$ & $0.75 \%$ & $1.5 \%$ & $0.75 \%$ & $1.5 \%$ & $0.75 \%$ & $1.5 \%$ \\
\hline \multirow{4}{*}{$\begin{array}{l}\text { Shoot Length } \\
\text { (cm) } \pm \text { SE }\end{array}$} & $1.10 \pm$ & $1.33 \pm$ & $0.70 \pm$ & $1.04 \pm$ & $0.56 \pm$ & $0.63 \pm$ & $1.08 \pm$ & $0.61 \pm$ & $1.46 \pm$ & $0.53 \pm$ \\
\hline & $0.061 \mathrm{ab}$ & $0.10 \mathrm{AC}$ & $0.02 \mathrm{~b}$ & $0.10 \mathrm{~A}$ & $0.03 \mathrm{~b}$ & $0.07 \mathrm{~B}$ & $0.07 \mathrm{a}$ & $0.05 \mathrm{~B}$ & $0.11 \mathrm{c}$ & $0.03 \mathrm{~B}$ \\
\hline & $38.88 \%$ & $26.55 \%$ & $61.45 \%$ & 42.59 & $69.08 \%$ & $65.10 \%$ & $40.43 \%$ & $66.43 \%$ & $19.41 \%$ & $70.58 \%$ \\
\hline & inhibition & inhibition & inhibition & inhibition & inhibition & inhibition & inhibition & inhibition & inhibition & inhibition \\
\hline \multirow{4}{*}{$\begin{array}{l}\text { Root Length } \\
(\mathrm{cm}) \pm \mathrm{SE}\end{array}$} & $0.98 \pm$ & $0.67 \pm 0.02$ & $0.52 \pm 0.05$ & $0.82 \pm 0.12$ & $0.22 \pm$ & $0.26 \pm$ & $2.17 \pm$ & $0.35 \pm$ & $0.90 \pm$ & $0.39 \pm$ \\
\hline & $0.05 \mathrm{a}^{\prime}$ & A'B'D' & b'c'd' & $A^{\prime} B^{\prime}$ & $0.01 \mathrm{c}$ & $0.02 \mathrm{C}^{\prime}$ & $0.23 \mathrm{e}^{\prime}$ & $0.04 \mathrm{C}^{\prime} \mathrm{D}$ ' & $0.03 \mathrm{a}^{\prime} \mathrm{b}^{\prime}$ & 0.03 C'D \\
\hline & $57.13 \%$ & $70.91 \%$ & $77.19 \%$ & $64.41 \%$ & $90.19 \%$ & $88.75 \%$ & $5.49 \%$ & $84.52 \%$ & $60.88 \%$ & $83.08 \%$ \\
\hline & inhibition & inhibition & inhibition & inhibition & inhibition & inhibition & inhibition & inhibition & inhibition & inhibition \\
\hline
\end{tabular}

Note. The means followed by the same letters and signs within same organ/extract concentration do not differ statistically by the Tukey test $(\mathrm{p}<0.05), \mathrm{n}=10$. SE: standard error.

Similarly, sesame root growth was also negatively affected by the extracts from both WT and GGR transgenic plants (Table 3). In this case, the concentration played a more determinant role in the reduction of root growth, as $1.5 \%$ dilutions induced the highest inhibition percentages (Table 3 ). Table 3 shows that GGR leaf extracts can induce an inhibition of root growth up to $90 \%$. Therefore, the most significant inhibition effects were observed with $1.5 \%$ extracts from $4 \mathrm{~GB}$ and $4 \mathrm{GM}$ (Table 3 ). It is noteworthy that, in $4 \mathrm{~GB}$ case, $0.75 \%$ was as effective as $1.5 \%$ extract (Table 3 ).

\subsubsection{Organic Solvent Leaf Extracts}

To evaluate the phytotoxic effects of WT and GGR transgenic plants on the growth of sesame, it was performed a bioassay with allelochemical compounds that could be extracted with organic solvent. Additionally, sesame seedlings were grown on leaf extracts from WT and the transgenic line 4GB diluted to 2000, 1000, and $500 \mathrm{ppm}$. Moreover, the effects of these extracts were compared with a negative control (water) as well as with sesame seedlings treated with the herbicide glyphosate with the same concentrations. As mentioned previously, the morphology of sesame seedlings treated with Arabidopsis organic solvent extracts was similar to that observed with those grown with aqueous extracts (Figure 2B).

Consistently, roots were more sensitive to organic extracts and glyphosate than shoots (Table 4). In fact, there was no significant effect of organic extracts on sesame shoot growth. Nevertheless, it could be observed that 4GB leaf organic extracts tended to affect more negatively sesame shoot growth (Table 4). As expected, glyphosate dilutions were very effective to inhibit sesame shoot growth (Table 4).

Table 4. Sesame (Sesamum indicum L.) seedlings shoot growth $(\mathrm{cm})$ treated with water/organic solvent, leaf extracts $(500,1000$, and $2000 \mathrm{ppm})$ from wild-type, 4GB Arabidopsis plants, and glyphosate (500, 1000, and $2000 \mathrm{ppm})$

\begin{tabular}{|c|c|c|c|c|c|c|c|c|c|c|}
\hline \multirow{2}{*}{ Treatment } & \multirow{2}{*}{ Control } & \multicolumn{3}{|c|}{ WT extracts } & \multicolumn{3}{|c|}{ 4GB extracts } & \multicolumn{3}{|c|}{ Glyphosate } \\
\hline & & $2000 \mathrm{ppm}$ & $1000 \mathrm{ppm}$ & $500 \mathrm{ppm}$ & $2000 \mathrm{ppm}$ & $1000 \mathrm{ppm}$ & $500 \mathrm{ppm}$ & $2000 \mathrm{ppm}$ & $1000 \mathrm{ppm}$ & $500 \mathrm{ppm}$ \\
\hline \multirow[t]{2}{*}{ Shoot Length (cm) $\pm \mathrm{SE}$} & $1.047 \pm$ & $0.775 \pm$ & $0.774 \pm$ & $0.846 \pm$ & $0.812 \pm$ & $0.752 \pm$ & $0.928 \pm$ & $0.243 \pm$ & $0.262 \pm$ & $0.272 \pm$ \\
\hline & $0.083 \mathrm{a}$ & $0.101 \mathrm{a}$ & $0.077 \mathrm{a}$ & $0.086 \mathrm{a}$ & $0.016 \mathrm{a}$ & $0.027 \mathrm{~b}$ & $0.087 \mathrm{a}$ & $0.035 \mathrm{c}$ & $0.009 \mathrm{c}$ & $0.010 \mathrm{c}$ \\
\hline$\%$ of Inhibition & - & 25.98 & 26.07 & 19.20 & 22.45 & 28.17 & 11.37 & 76.79 & 74.98 & 74.02 \\
\hline
\end{tabular}

Note. The means followed by the same letters do not differ statistically by the Tukey test $(\mathrm{p}<0.05), \mathrm{n}=10$. SE: standard error. 
Differently, both WT and 4GB leaf extracts were highly inhibitory on sesame roots (Table 5). Therefore, all extract concentrations (WT and 4GB) significantly reduced root growth of sesame seedlings by 30 to $70 \%$ (Table 5). Furthermore, the most effective extract dilution was $2000 \mathrm{ppm}$ for both Arabidopsis lines. Moreover, 4GB organic extracts $(2000 \mathrm{ppm})$ significantly reduced sesame root elongation by approximately $70 \%$, which was the most effective leaf extract regarding root growth reduction (Table 5). Like what had been observed in shoots, all glyphosate concentrations induced the greatest growth reduction effect on sesame roots. Sesame roots practically did not grow in the presence of glyphosate (Table 5).

Table 5. Growth $(\mathrm{cm})$ of sesame (Sesamum indicum L.) roots grown with water, leaf extracts $(500$, 1000, and 2000 ppm) from wild-type, 4GB Arabidopsis plants, and glyphosate (500, 1000, and $2000 \mathrm{ppm}$ )

\begin{tabular}{|c|c|c|c|c|c|c|c|c|c|c|}
\hline \multirow{2}{*}{ Treatment } & \multirow{2}{*}{ Control } & \multicolumn{3}{|c|}{ WT extracts } & \multicolumn{3}{|c|}{ 4GB extracts } & \multicolumn{3}{|c|}{ Glyphosate } \\
\hline & & $2000 \mathrm{ppm}$ & $1000 \mathrm{ppm}$ & $500 \mathrm{ppm}$ & $2000 \mathrm{ppm}$ & $1000 \mathrm{ppm}$ & $500 \mathrm{ppm}$ & $2000 \mathrm{ppm}$ & $1000 \mathrm{ppm}$ & $500 \mathrm{ppm}$ \\
\hline \multirow[t]{2}{*}{ Root Length $(\mathrm{cm}) \pm \mathrm{SE}$} & $1.867 \pm$ & $0.848 \pm$ & $0.774 \pm$ & $1.203 \pm$ & $0.555 \pm$ & $0.897 \pm$ & $1.222 \pm$ & $0.012 \pm$ & $0.045 \pm$ & $0.059 \pm$ \\
\hline & $0.272 \mathrm{~A}$ & $0.087 \mathrm{~B}$ & $0.095 \mathrm{~B}$ & $0.074 \mathrm{~B}$ & $0.046 \mathrm{C}$ & $0.141 \mathrm{~B}$ & $0.065 \mathrm{~B}$ & $0.008 \mathrm{D}$ & $0.002 \mathrm{D}$ & $0.016 \mathrm{D}$ \\
\hline$\%$ of Inhibition & - & 54.58 & 58.54 & 35.57 & 70.27 & 51.96 & 34.55 & 99.36 & 97.56 & 96.84 \\
\hline
\end{tabular}

Note. The means followed by the same letters do not differ statistically by the Tukey test $(\mathrm{p}<0.05), \mathrm{n}=10$. SE: standard error.

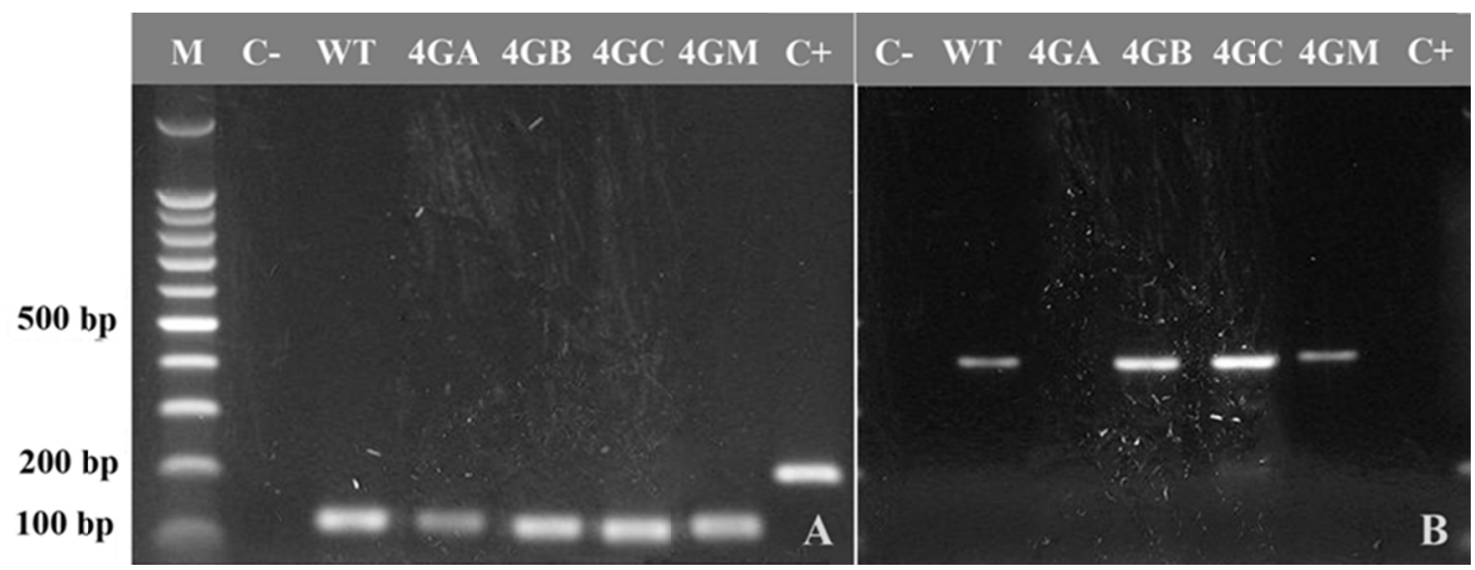

Figure 3. Analysis of genomic DNA contamination by PCR amplification with the primers of actin2 and EF1 $\alpha$ genes. A) PCR products had a size of higher than 100 bp for cDNA samples from wild type (WT); and $G G R$ lines 4GA; 4GB; 4GC; and 4GM. B) The PCR amplification of cDNA samples from WT, 4GB, 4GC, and 4GM produced amplicons of about $400 \mathrm{bp}$. The size of the PCR products from both genes are compatible with amplification of cDNA samples without any trace of genomic DNA. (C-) Negative control-water. (C+) Positive control-genomic DNA from wild-type Arabidopsis thaliana. (M) 100 bp Molecular Marker (Invitrogen ${ }^{\mathrm{TM}}$ )

\subsection{Analysis of GGR Expression by Real Time PCR}

Before initiating the analysis of $G G R$ expression by real time PCR, it was necessary to confirm that the cDNA samples were free of genomic contamination. Thus, PCR amplification using primers for actin2 (primer actin2 forward and reverse) and elongation factor (primer EFl $\alpha$ forward and reverse) to determine the presence or absence of introns, which allows the distinction between cDNA and endogenous contaminating DNA. Furthermore, the results showed that the amplified regions had the size of $131 \mathrm{bp}$ for the actin2 gene and $404 \mathrm{bp}$ for EF1 $\alpha$ (Figures 3A and 3B). The actual sizes of the amplicons point to a total removal of the introns from both genes, which confirmed that the template for PCR amplification was the cDNA. Nonetheless, there was no amplification of actin2 gene in 4GA samples, neither was in the genomic DNA used as positive control (Figure $3 \mathrm{~A})$.

\subsubsection{GGR Expression in WT Arabidopsis and Transgenic Lines}

The level of GGR expression was evaluated in the transgenic lines and WT Arabidopsis plants relative to ACT8 and $R A D 23 C$ constitutive genes. The surprising fact is that, compared with WT, GGR expression levels were 
lower in all transgenic lines, which were supposed to overexpress it (Figures 4 and 5). Furthermore, the results also revealed no significant differences in GGR expression amid the transgenic lines (Figures 4 and 5). Similarly, compared with WT plants, the transgenic lines $4 \mathrm{GA}, 4 \mathrm{~GB}$, and $4 \mathrm{GC}$ did not have significant differences for either $A C T 8$ or RAD23C (Figures 4 and 5). Nonetheless, in 4GM line, GGR expression was significantly lower than in WT plants for both reference genes (Figures 4 and 5).

Although not statistically significant for most of transformed lines, the expression levels of $G G R$ were consistently lower in transgenic lines than in WT plants for both reference genes. Moreover, for ACT8, GGR relative expressions were about 2-(for lines $4 \mathrm{GA}$ and $4 \mathrm{GC}$ ) to 26 -fold lower (for line $4 \mathrm{GM}$ ) than in WT plants. For $R A D 23 C$ reference gene, $G G R$ relative expression reduction in transgenic lines was about 1.5-(for the line 4GC) to 23-fold (for the line 4GM) when compared with WT samples (Figures 4 and 5).

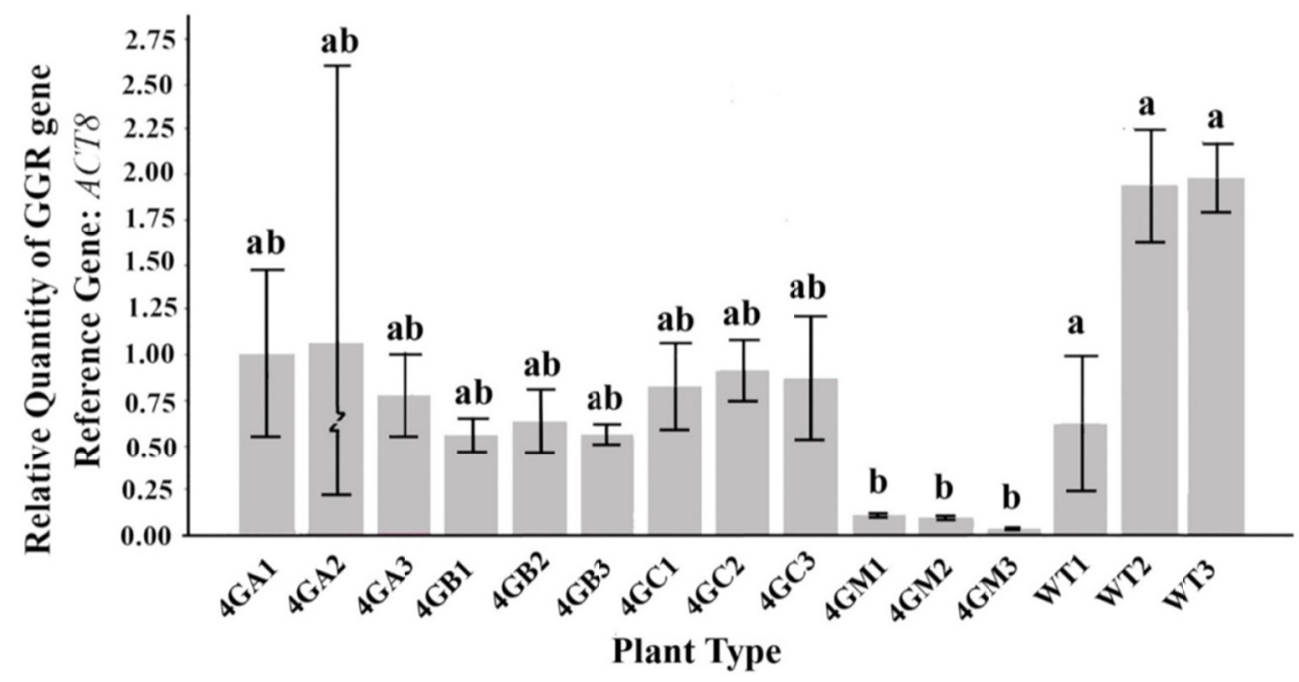

Figure 4. Relative expression analysis of the GGR gene compared with ACT8 (AT1G49240) reference gene in five-week-old Arabidopsis thaliana leaf samples from WT and GGR lines. The means followed by the same letters do not differ statistically by the Student's t test $(\mathrm{p}<0.05)$. Error bars $=$ standard error

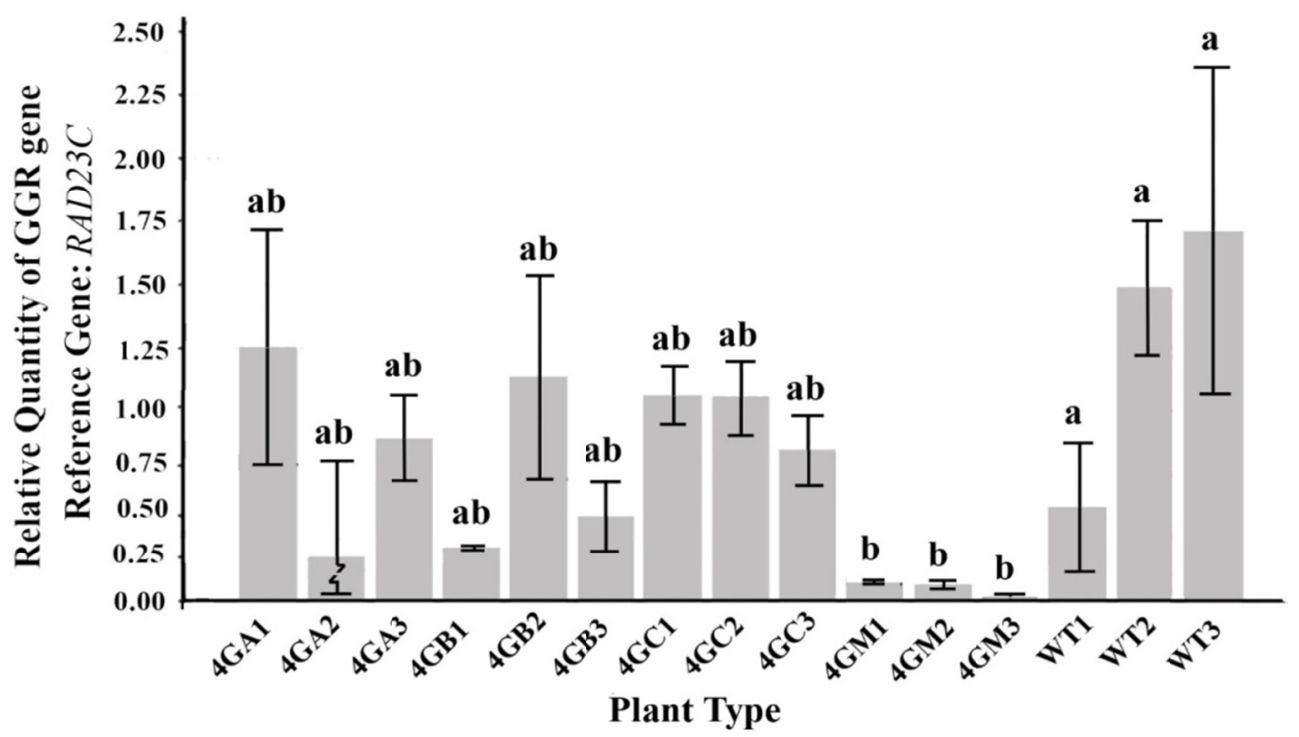

Figure 5. Relative expression analysis of the GGR gene in comparison with RAD23C (At3G02540) gene in five-week-old Arabidopsis thaliana leaf samples from WT and GGR lines. The means followed by the same letters do not differ statistically by the Student's t test $(\mathrm{p}<0.05)$. Error bars $=$ standard error 


\section{Discussion}

\subsection{Leaf Extracts From WT and GGR Transgenic Arabidopsis Lines Inhibited Sesame Growth}

Arabidopsis has been used as a model plant for different purposes, which includes allelopathy. Therefore, there have been reports on allelopathic effects of Arabidopsis seeds (Tomita-Yokotani et al., 2003), germinating seeds (Tomita-Yokotani, Goto, Kosemura, Yamamura, \& Hasegawa, 1997), as well as target plants (Schulz et al., 2007; Kato-Noguchi \& Kitajima, 2015). To the best of our knowledge, there have not been studies on the phytotoxicity of Arabidopsis leaf compounds on other plants. Therefore, the data indicating that Arabidopsis leaf extracts have a strong inhibitory effect on the growth of sesame seedlings is an interesting fact.

Besides, several morphological and physiological effects were observed in sesame seedlings exposed to Arabidopsis extracts (aqueous/organic solvent). Sesame roots showed a defective gravitropic response when grown in the presence of the extracts. Additionally, hypocotyl hypertrophy, tissue oxidation, root shortness, and higher thickness of the roots were seen in extracted exposed seedlings (Figure 2A). These morphological changes and impaired gravitropism are consistent with the allelopathic responses elicited by other plants. Hence, similar morphological changes and in the gravitropic response were triggered by Eugenia dysenterica allelochemicals in radish and sesame seedlings (Pereira et al., 2017). Moreover, there is also consistency in the fact that roots are more sensitive to allelochemicals than shoots (Pina et al., 2009; Pereira et al., 2017).

The fact that WT Arabidopsis leaf extracts (aqueous/organic) had allelopathic effects on sesame seedlings is important, perhaps not yet reported. However, equally significant was the observation that changing the expression of an enzyme involved in terpene synthesis, not only altered, but enhanced the allelopathic response of sesame seedlings to Arabidopsis extracts. Thus, the data indicates a direct connection between GGR expression levels and allelopathic response.

\subsection{GGR Expression and Allelopathic Effects on Sesame}

GGR gene (At4g38640) expression is considered constitutive in leaves, stems, flowers, and roots of Arabidopsis. Beck et al. (2013) identified 12 genes coding for GGPP synthase (GGPPS) family in Arabidopsis, and the GGR (geranylgeranyl reductase) gene was termed as GGPPS12 by these authors. Moreover, GGR protein has the lowest amino acid sequence similarity among all Arabidopsis GGPPS, and, alone, it does not act as an active enzyme (Okada 2000; Wang \& Dixon, 2009). Moreover, GGR forms a heterodimeric with GGPPS1 (GGPPS11, Beck et al., 2013) with highly catalytic efficiency, which is directly involved in the synthesis of monoterpenes (Wang \& Dixon, 2009; Chen et al., 2015). Additionally, it has been suggested that GGPPS1-GGR heterodimeric might be the main route for the synthesis of monoterpenes in Arabidopsis (Chen et al., 2015).

Monoterpenes and diterpenes have been shown to possess allelopathic activity. For instance, the exposure to camphor and menthol, both monoterpenes, enhanced transpiration because of uncontrolled stomatal opening of Arabidopsis fully developed rosette leaves (Schulz et al., 2007). In rice diterpenoid momilactones work as allelochemicals and suppress the growth of barnyard grass weed (Xu et al., 2012). Therefore, terpene synthesis and allelopathic response are interdependent. Hence, the overexpression of genes related to terpene synthesis could be relevant to genetically engineer plants towards a more effective allelopathic response, and, thereby, of environmental interest for weed control.

Although not intended, it is not unusual that attempts to overexpress a transgene may trigger the suppression or reduction of the expression of the endogenous homologous gene along with the transgene (Meyer \& Saedler, 1996; Wang et al., 2012). Homology-dependent gene silencing (HDGS) can occur due to multiple gene copies in a genome. There are two different mechanisms in HDGS, the transcriptional gene silencing (TPS) and post-transcriptional gene silencing (PTGS). TGS takes place when the transcription of transgenes is blocked due to methylation of the promoter, which prevents the transcriptional machinery to initiate the process (Rajeevkumar, Anunanthini, \& Sathishkumar, 2015). PTGS is a consequence of transgene and endogenous mRNA degradation in the cytosol (Rajeevkumar et al., 2015). Real time expression analysis indicates that GGR was being transcribed, however, its expression was impaired in all transgenic lines. It suggests that a PTGS phenomenon took place in GGR lines. Nonetheless, the fact that GGR lines had higher phytotoxicity than WT plants came up as a surprise.

As mentioned, terpenes contents are frequently associated with increased allelopathic effects on target plants. Thus, a decrease of GGR expression, which is part of the most important pathway of monoterpene synthesis in Arabidopsis (Chen et al., 2015), should have resulted in lower phytotoxicity of the transgenic lines. Nonetheless, it appears that this line of thinking is an oversimplification of a complex matter. Metabolism is seldom a straight series of events. A disturbance in one metabolic route can usually affect one or more associated pathways, which 
might result in changes in quantities and/or types of metabolite produced. For instance, the repression or overexpression of MSYABBY5, a transcription factor expressed in glandular trichome of spearmint plants, resulted in different outcomes concerning monoterpene production (Wang et al., 2016). A reduced expression of $M s Y A B B Y 5$ enhanced monoterpene production and MsYABBY5 overexpression decreased the amounts of these compounds in transgenic plants (Wang et al., 2016). In this specific case, the changes in monoterpene production were not due to a HDGS as MSYABBY5 was considered a repressor of secondary metabolism (Wang et al., 2016).

Furthermore, a recent study showed that the use of substrates such as GGPP is competitive and may change the type of terpenes produced depending on the route that is privileged. In rice (Oryza sativa L.), the overexpression of OsGRP (GGPPS recruiting protein) decreases the synthesis of carotenoid and gibberellins (diterpenoids) because $O s G R P$ overexpressing transgenic rice was more capable of using the GGPP supply (Zhou et al., 2017). Additionally, OsGGPPS1, OsGRP and OsGGR, are constituents of a multiprotein complex in chloroplast of rice and is associated with GGPP production, which might be used for the synthesis of either chlorophyll or carotenoids and other terpenes (Zhou et al., 2017). In Arabidopsis, GGPPS1 can also interact with GGR (Wang \& Dixon, 2009; Chen et al., 2015). Moreover, GGPPS1 works as a hub in Arabidopsis chloroplast terpene biosynthesis and GGPP use may favour the production of different terpenes (Ruiz-Sola et al., 2016). If GGPPS1 interacts with GGR, the use of GGPP is directed towards phytyl-PP, chlorophylls, tocopherols, and phylloquinones (Ruiz-Sola et al., 2016). However, if the interaction is with the PSY (phytoene synthase) the final products are diterpenes (gibberellin), phytoene, carotenoids, and many other terpenes (Ruiz-Sola et al., 2016). It is noteworthy to say that these enzyme interactions take place only in green tissues.

Based on that, three consistent observations can be made with regards GGR overexpressing Arabidopsis lines. First, the decreased expression levels of GGR may have altered the usage of GGPP. Secondly, the use of the substrate GGPP could have favoured the production of terpenes that do not require the involvement of GGR protein such as diterpenoids, carotenoids, ABA, and strigolactones. Finally, the types of terpenes produced have stronger allelopathic effects than those that would have been produced if GGR/GGPPS1 interaction had been privileged.

Nonetheless, we intent to investigate these issues through proteomic and metabolomic approaches to compare Arabidopsis WT and GGR lines to determine which proteins and metabolic compounds are involved in the allelopathic response observed in this plant.

\section{Conclusions}

The current investigation has been established a direct correlation between terpenes and allelopathy. Furthermore, it appears that the type of terpenes affects the intensity of allelopathic response. Another interesting aspect is the fact that Arabidopsis leaves induced a strong allelopathic reaction, which resulted in growth inhibition of target plants. There are a few reports on Arabidopsis as target plant, as well as with respect the use of its seed as plant growth enhancer (Tomita-Yokotani et al., 2003; Kato-Noguchi \& Kitajima 2015). Nonetheless, to the best of our knowledge, we have not heard that Arabidopsis leaf compounds can inhibit plant growth. This fact makes this plant, in our understanding, a very interesting model to study the allelopathy phenomenon at molecular level, because Arabidopsis genome has been fully sequenced, and it is available to everyone. Thereby, it becomes a crucial research tool, which can produce rapid advances of researches on weed control and allelochemicals. Nevertheless, it is necessary to identify the actual compounds present in allelochemicals as well as to focus on metabolic pathways and mechanisms that control allelopathy. We certainly have taken a step in this direction. Finally, the findings of the present investigation have the potential to open new ways that may lead to the synthesis of environmentally friendly compounds for weed control.

\section{References}

Amali, J. P., Jayasurya, K. S., \& Ignacimuthu, S. (2014). Sorgoleone from Sorghum bicolor as a potent bioherbicide. Research Journal of Recent Sciences, 3, 32-36.

Auburg, S., Lecharny, A., \& Bohlmann, J. (2002). Genomic analysis of the terpenoid synthase (AtTPS) gene family of Arabidopsis thaliana. Molecular Genetics and Genomics, 6, 730-745. https://doi.org/10.1007/ s00438-002-0709-y

Beck, G., Coman, D., Herren, E., Ruiz-Sola, M. A., Rodríguez-Concepción, M., Gruissem, W., \& Vranová, E. (2013). Characterization of the GGPP synthase gene family in Arabidopsis thaliana. Plant Molecular Biology, 82, 393-416. https://doi.org/10.1007/s11103-013-0070-z

Carretero-Paulet, L., Ahumada, I., Cunillera, N., Rodríguez-Concepción, M., Ferrer, A., Boronat, A., \& Campos, N. (2002). Expression and molecular analysis of the Arabidopsis DXR gene enconding 1-deoxy-d-xylulose 
5-phosphate reductoisomerase, the first committed enzyme of the 2-C-Methyl-D-Erythritol 4-Phosphate pathway. Plant Physiology, 129, 1581-1591. https://doi.org/10.1104/pp.003798

Chao, Y., Kang, J., Zhang, T., Yang, Q., Gruber, M. Y., \& Sun, Y. (2014). Disruption of the homogentisate solanesyltransferase gene results in albino and dwarf phenotypes and root, trichome and stomata defects in Arabidopsis thaliana. PLoS ONE, 9(4), e94031. https://doi.org/10.1371/journal.pone.0094031

Chen, Q., Fan, D., \& Wang, G. (2015). Heteromeric geranyl(geranyl)diphosphate synthase is involved in monoterpene biosynthesis in Arabidopsis flowers. Molecular Plant, 8, 1434-1437. https://doi.org/10.1016/ j.molp.2015.05.001

Cheng, F., \& Cheng, Z. (2015). Research progress on the use of plant allelopathy in agriculture and the physiological and ecological mechanisms of allelopathy. Frontiers in Plant Science, 6, 1020. https://doi.org/ $10.3389 /$ fpls.2015.01020

Demain, A. L., \& Fang, A. (2000). The natural functions of secondary metabolites. Advances in Biochemical Engineering/Biotechnology, 69, 1-39. https://doi.org/10.1007/3-540-44964-7_1

Formagio, A. S. N., Masetto, T. E., Baldivia, D. S., Vieira, M. C., Zárate, N. A. H., \& Pereira, Z. V. (2010). Allelopathic potential of five species of the Annonaceae Family. Brazilian Journal of Bioscience, 8, 349-354. https://doi.org/10.1590/S0102-33062012000400007

Gomaa, N. H., Hassan, M. O., Fahmy, G. M., González, L., Hammouda, O., \& Atteya, A. M. (2014). Allelopathic effects of Sonchus oleraceus L. on the germination and seedling growth of crop and weed species. Acta Botanica Brasilica, 28, 408-416. https://doi.org/10.1590/0102-33062014abb3433

Harrison, S. J., Mott, E. K., Parsley, K., Aspinall, S., Gray, J. C., \& Cottage, A. (2006). A rapid and robust method of identifying transformed Arabidopsis thaliana seedlings following floral dip transformation. Plant Methods, 2, 19. https://doi.org/10.1186/1746-4811-2-19

Johnson, R. H., Hull-Sanders, H. M., \& Meyer, G. A. (2007). Comparison of foliar terpenes between native and invasive Solidago gigantea. Biochemical Systematics and Ecology, 35, 821-830. https://doi.org/10.1016/ j.bse.2007.06.005

Kato-Noguchi, H., \& Kitajima, S. (2015). Momilactone sensitive proteins in Arabidopsis thaliana. Natural Product Communications, 10, 729-732.

Keller, Y., Bouvier, F., D’Harlingue, A., \& Camara, B. (1998). Metabolic compartmentation of plastid prenyllipid biosynthesis, evidence for the involvement of a multifunctional geranylgeranyl reductase. European Journal of Biochemistry, 251, 413-417. https://doi.org/10.1046/j.1432-1327.1998.2510413.x

Kliebenstein, D. J. (2004). Secondary metabolites and plant/environment interactions: A view through Arabidopsis thaliana tinged glasses. Plant, Cell and Environment, 27, 675-684. https://doi.org/10.1111/ j.1365-3040.2004.01180.x

Maimone, T. J., \& Baran, P. S. (2007). Modern synthetic efforts toward biologically active terpenes. Nature Chemical Biology, 3, 396-407. https://doi.org/10.1038/nchembio.2007.1

Meyer, P., \& Saedler, H. (1996). Homology-dependent gene silencing in plants. Annual Review of Plant Physiology and Plant Molecular Biology, 47, 23-48. https://doi.org/10.1146/annurev.arplant.47.1.23

Murashige, T., \& Skoog, F. (1962). A revised medium for rapid growth and bioassays with tobacco tissue culture. Physiologia Plantarum, 15, 473-497. https://doi.org/10.1111/j.1399-3054.1962.tb08052.x

Okada, K., Nakagawa, T., Kawamukai, M., \& Kamiya, Y. (2000). Five geranylgeranyl diphosphate synthases expressed in different organs are localized into three subcellular compartments in Arabidopsis. Plant Physiology, 122, 1045-1056. https://doi.org/10.1104/pp.122.4.1045

Pereira, L. A. R., Pina, G. O., Silveira, C. E. S., Gomes, S. M., Toledo, J. L., \& Borghetti, F. (2017). Effects of Eugenia dysenterica L. extracts on roots and gravitropism of Sesamum indicum L. and Raphanus sativus L. Allelopathy Journal, 42, 03-20. https://doi.org/10.26651/2017-42-1-1102

Pina, G. O., Borghetti, F., Silveira, C. E. S., \& Pereira, L. A. R. (2009). Effects of Eugenia dysenterica leaf extracts on the growth of sesame and radish. Allelopathy Journal, 23, 313-322.

Rajeevkumar, S., Anunanthini, P., \& Sathishkumar, R. (2015). Epigenetic silencing in transgenic plants. Frontiers in Plant Science, 6. https://doi.org/10.3389/fpls.2015.00693 
Rodríguez-Concepción, M., \& Boronat, A. (2001). Elucidation of the methylerythritol phosphate pathway for isoprenoid biosynthesis in bacteria and plastids. A metabolic milestone achieved through genomics. Plant Physiology, 130, 1079-1089. https://doi.org/10.1104/pp.007138

Rubio, V., Shen, Y., Saijo, Y., Liu, Y., Gusmaroli, G., Dinesh-Kumar, S. P., \& Deng, X. W. (2005). An alternative tandem affinity purification strategy applied to Arabidopsis protein complex isolation. Plant Journal, 41, 767-778. https://doi.org/10.1111/j.1365-313X.2004.02328.x

Ruiz-Sola, M. A., Coman, D., Beck, G., Barja, M. V., Colinas, M., Graf, A., ... Vranová, E. (2016). Arabidopsis geranylgeranyl diphosphate synthase 11 is a hub isozyme required for the production of most photosynthesis-related isoprenoids. New Phytologist, 209, 252-264. https://doi.org/10.1111/nph.13580

Schulz, M., Kussmann, P., Knop, M., Kriegs, B., Gresens, F., Eichert, T., ... Noga, G. (2007). Allelopathic monoterpenes interfere with Arabidopsis thaliana cuticular waxes and enhance transpiration. Plant Signaling and Behavior, 2, 231-239. https://doi.org/10.4161/psb.2.4.4469

Scolnik, P. A., \& Bartley, G. E. (1994). Nucleotide sequence of an Arabidopsis cDNA for geranylgeranyl pyrophosphate synthase. Plant Physiology, 104, 1469-1470. https://doi.org/10.1104/pp.104.4.1469

Soltys, D., Krasuska, U., Bogatek, R., \& Gniazdowska, A. (2013). Allelochemicals as bioherbicides-Present and perspectives. In A. J. Price, \& J. A. Kelton (Eds.), Herbicides-Current Research and Case Studies in Use (pp. 517-542). Intechopen. https://doi.org/10.5772/56185

Tholl, D., \& Lee, S. (2011). Terpene specialized metabolism in Arabidopsis thaliana. The Arabidopsis Book, 9, e0143. https://doi.org/10.1199/tab.0143

Tomita-Yokotani, K., Goto, N., Kosemura, S., Yamamura, S., \& Hasegawa, K. (1997). Growth-promoting allelopathic substance exuded from germinating Arabidopsis thaliana seeds. Phytochemistry, 47, 1-2. https://doi.org/10.1016/S0031-9422(97)00532-3

Tomita-Yokotani, K., Kato, T., Parvez, M. M., Mori, Y., Goto, N., \& Hasegawa, K. (2003). Approach of allelopathy study with Arabidopsis thaliana (L.) Hevnh. and Neurospora crassa. Weed Biology and Management, 3, 93-97. https://doi.org/10.1046/j.1445-6664.2003.00089.x

Valduga, E., Tatsch, P. O., Tiggemann, L., Treichel, H., Toniazzo, G., Zeni, J., ... Júnior, A. F. (2009). Carotenoids production: Microorganisms as source of natural dyes. Quimica Nova, 32, 2429-2436. https://doi.org/10.1590/S0100-40422009000900036

Vandermoten, S., Haubruge, E., \& Cusson, M. (2009). New insights into short-chain prenyltransferases: structural features, evolutionary history and potential for selective inhibition. Cellular and Molecular Life Sciences, 66, 3685-3695. https://doi.org/10.1007/s00018-009-0100-9

Wang, G., \& Dixon, R. A. (2009). Heterodimeric geranyl(geranyl)diphosphate synthase from hop (Humulus lupulus) and the evolution of monoterpene biosynthesis. Proceedings of the National Academy of Sciences, 106, 9914-9919. https://doi.org/10.1073/pnas.0904069106

Wang, Q., Reddy, V. A, Panicker, D., Mao, H.-Z., Kumar, N., Rajan, C., ... Sarojam, R. (2016). Metabolic engineering of terpene biosynthesis in plants using a trichome-specific transcription factor MsYABBY5 from spearmint (Mentha spicate). Plant Biotechnology Journal, 14, 1619-1632. https://doi.org/10.1111/pbi.12525

Wang, X., Wang, P., Sun, S., Darwiche, S., Idnurm, A., \& Heitman, J. (2012). Transgene induced co-suppression during vegetative growth in Cryptococcus neoformans. PLoS Genetics, 8, e1002885. https://doi.org/ 10.1371/journal.pgen.1002885

Wanke, M., Skorupinska-Tudek, K., \& Swiezewska, E. (2001). Isoprenoid biosynthesis via 1-deoxy-D-xylulose 5-phosphate/2-C-methyl-D-erythritol 4-phosphate (DOXP/MEP) pathway. Acta Biochimica Polonica, 48, 663-672.

Wong, M. L., \& Medrano, J. F. (2005). Real-time PCR for mRNA quantification. Biotechniques, 39 , 75-85. https://doi.org/10.2144/05391RV01

Xu, M., Galhano, R., Wiemann, P., Bueno, E., Tiernan, M., Wu, W., .. Peters, R. J. (2012). Genetic evidence for natural product-mediated plant-plant allelopathy in rice (Oryza sativa). New Phytologist, 193, $570-575$. https://doi.org/10.1111/j.1469-8137.2011.04005x 
Zhou, F., Wang, C.-Y., Gutensohn, M., Jiang, L., Zhang, P., Zhang, D., ... Lu, S. (2017). A recruiting protein of geranylgeranyl diphosphate synthase controls metabolic flux toward chlorophyll biosynthesis in rice. Proceedings of the National Academy of Sciences, 114, 6866-6871. https://doi.org/10.1073/pnas.17056 89114

\section{Copyrights}

Copyright for this article is retained by the author(s), with first publication rights granted to the journal.

This is an open-access article distributed under the terms and conditions of the Creative Commons Attribution license (http://creativecommons.org/licenses/by/4.0/). 